\title{
Factor XII Deficiency
}

National Cancer Institute

\section{Source}

National Cancer Institute. Factor XII Deficiency. NCI Thesaurus. Code C131740.

A coagulation disorder characterized by the partial or complete absence of factor XII activity in the blood. It is not associated with increased bleeding risk. 